\title{
MALAT1 Gene
}

National Cancer Institute

\section{Source}

National Cancer Institute. MALAT1 Gene. NCI Thesaurus. Code C92696.

This gene may play a role in carcinogenesis. 